\title{
PENGEMBANGAN MEDIA KOMIK DENGAN PENDEKATAN SAINTIFIK UNTUK MENINGKATKAN KEMAMPUAN PEMECAHAN MASALAH MATEMATIKA SD
}

\author{
Danang Pamungkas, Wahyudi, Endang Indarini \\ danangpamungkas602@ gmail.com, yudhi@staff.uksw.edu, eindarini@ gmail.com \\ Pendidikan Guru Sekolah Dasar, Universitas Kristen Satya Wacana Salatiga, Indonesia
}

\begin{abstract}
This research and development aims to develop and test the validity, practicality, and effectiveness of comic-based modules in mathematics in elementary schools. The research method used is $R \& D$ with the ADDIE development model which consists of five stages, namely 1) analysis, 2) design, 3) development, 4) implementation, and 5) evaluation ). Product validity was obtained from expert testing with expert validation instruments. The practicality of the product in the form of comic media was obtained through limited trials with a questionnaire instrument. The effectiveness is obtained through one class trial with one group pretest posttest design then the results are tested using Paired SamplesvT Test. The result of this research is that the comic-based media module generally improves the ability to solve mathematical problems in the classroom material of five elementary school students. Learning media are declared valid based on the test of media experts, material experts and learning experts. Learning media are declared practical based on the results of the questionnaire responses of teachers and students. Learning media are declared effective based on the results of students' Paired SamplesvT Test pretest posttest.
\end{abstract}

Keywords: development, modules, comics, problem solving ability

\section{ABSTRAK}

Penelitian dan pengembangan ini bertujuan untuk mengembangkan dan menguji kevalidan, kepraktisan, dan keefektifan, modul berbasis komik pada mata pelajaran matematika di sekolah dasar. Metode penelitian yang digunakan adalah R\&D dengan model pengembangan ADDIE yang terdiri dari lima tahap yaitu 1) analysis (analisis), 2) design (perancangan), 3) development (pengembangan), 4) implementation (implementasi), dan 5) evaluation (evaluasi). Kevalidan produk diperoleh dari uji pakar dengan instrument validasi pakar. Kepraktisan produk berupa media komik diperoleh melalui uji coba terbatas dengan instrument angket. Keefektifan diperoleh melalui uji coba satu kelas dengan one group pretest posttest design kemudian hasilnya diuji menggunakan Paired SamplesvT Test. Hasil dari penelitian pengembangan ini adalah media modul berbasis komik untuk meningkatkan kemampuan pemecahan masalah matematika pada materi bangun ruang kelas lima siswa sekolah dasar. Media pembelajaran dinyatakan valid berdasarkan uji pakar media, pakar materi dan pakar pembelajaran. Media pembelajaran dinyatakan praktis berdasarkan hasil angket respon guru dan siswa. Media pembelajaran dinyatakan efektif berdasarkan hasil Paired Samples T Test pretest posttest siswa.

Kata Kunci: pengembangan, modul, komik, kemampuan pemecahan masalah

\begin{tabular}{|c|c|c|}
\hline Submitted & Accepted & Published \\
\hline 24 Juli 2019 & 18 Oktober 2019 & 15 November 2019 \\
\hline
\end{tabular}

\begin{tabular}{|l|c|c|}
\hline Citation & $:$ & $\begin{array}{r}\text { Pamungkas, D., Wahyudi., \& Indarini, E. (2019). Pengembangan Media Komik dengan Pendekatan Saintifik untuk } \\
\text { Meningkatkan Kemampuan Pemecahan Masalah Matematika SD. Jurnal PAJAR (Pendidikan dan Pengajaran), } \\
\text { 3(6), 1405-1413. DOI : http://dx.doi.org/10.33578/pjr.v3i6.7904. }\end{array}$ \\
\hline
\end{tabular}

\section{PENDAHULUAN}

Pendidikan merupakan salah satu hal yang mendasar untuk dapat dijadikan tumpuan dalam meraih sebuah kesuksesan. Hal ini dikarenakan semakin tingginya tuntutan perkembangan jaman yang membuat Sumber Daya Manusia harus memiliki daya saing agar dapat bertahan di jaman yang semakin berkembang. Menurut UU Nomor 20 Tahun 2003 tentang Sistem Pendidikan Nasional pada Bab 2 Pasal 3 menjelaskan bahwa pendidikan di
Indonesia bertujuan untuk mengembangkan potensi peserta didik agar menjadi manusia yang beriman dan bertakwa kepada Tuhan Yang Maha Esa, berakhlak mulia, sehat, berilmu, cakap, kreatif, mandiri, dan menjadi warga negara yang demokratis serta bertanggung jawab. Untuk mencapai tujuan dari pendidikan nasional itu sendiri diperlukan peran dari berbagai aspek dalam pendidikan. Aspek-aspek yang diperlukan dalam pendidikan itu sendiri berasal dari guru, 
siswa, sistem pendidikan, dan infrastruktur pendidikan.

Dari permasalahan yang ada maka dalam pembelajaran di kelas guru memerlukan bahan ajar agar dapat memudahkan serta menarik minat siswa dalam belajar. Bahan ajar merupakan materi pelajaran lengkap yang disusun secara sistematis yang dapat dipakai oleh guru serta siswa yang disusun berdasarkan prinsip pembelajaran. Bahan dibagi menjadi bahan ajar cetak dan non cetak. Bahan ajar cetak ini dapat berupa modul, lembar kerja siswa, handout, serta buku teks. Sedangkan bahan ajar non cetak ini dapat berupa video, audio serta media interaktif yang berguna bagi pembelajaran (Ariastutik, dkk, 2016).

Kemampuan pemecahan masalah matematis merupakan salah satu kemampuan yang perlu dikuasai siswa saat belajar matematika. Hal ini dapat dipelajari mulai dari usia sekolah dasar. Satuan pendidikan sebagai tempat untuk mengembangkan kemampuan siswa hendaknya melaksanakan proses pembelajaran secara interaktif, inspiratif, menyenangkan, menantang, memotivasi siswa untuk berpartisipasi aktif, serta memberikan ruang yang cukup bagi prakarsa, kreativitas dan kemandirian sesuai dengan bakat, minat dan perkembangan fisik serta psikologis sosial (Permendikbud Nomor 22 Tahun 2016). Hal tersebut tidak terlepas dari peran guru dalam proses pembelajaran yakni (1) guru sebagai demonstrator dengan melakukan penguasaan bahan dan materi yang akan diajarkan, (2) guru sebagai pengelola kelas dilakukan dengan penanganan pada struktur kelas, (3) guru sebagai mediator dan fasilitator, serta (4) guru sebagai evaluator dengan melakukan penilaian terhadap tujuan, materi serta metode yang digunakan (Rusman, 2016).

Berdasarkan dua jenis bahan ajar tersebut, peneliti memilih mengembangkan bahan ajar cetak dikarenakan tidak semua sekolah sudah tersedia sarana dalam menampilkan bahan ajar non cetak. Dengan pemilihan bahan ajar cetak ini, sekolah yang masih belum terjangkau oleh teknologi maju dapat memakai bahan ajar cetak ini dalam mengajarkan kepada siswa. Fokus pembuatan bahan ajar cetak ini yaitu pada pembuatan modul pembelajaran. Modul itu sendiri adalah bahan ajar cetak yang didalamnya memuat materi, lembar kegiatan, lembar kerja, serta lembar evaluasi yang dapat digunakan oleh guru maupun siswa dalam pembelajaran. Dalam penyusunan modul guru harus memperhatikan penyusunan kata agar tidak menimbulkan penafsiran yang membuat siswa menjadi bingung. Di dalam modul juga harus memuat gambargambar dan ilustrasi yang menarik agar siswa menjadi minat untuk mempelajari modul yang sudah dibuat tersebut. Modul ini disusun agar memudahkan guru dalam menyajikan materi kepada siswa dan siswa dapat mempelajarinya sendiri baik di sekolah maupun dirumah.

Untuk menunjang kegiatan belajar siswa agar dapat lebih menarik lagi, maka peneliti mengembangkan bahan ajar Komik berbasis modul pada materi matematika Kelas V Sekolah Dasar. Peneliti memilih komik berbasis modul karena siswa lebih cenderung tertarik dan mudah dalam mempelajari jika pembelajaran terdapat gambar serta ilustrasi. Berbanding pada modulmodul yang dihasilkan oleh peneliti sebelumnya hanya sekedar materi dan gambar komik saja, namun pada modul dari peneliti kali ini materi pembelajaran dilengkapi dengan kegiatankegiatan yang dapat membuat siswa aktif dalam belajar. Selain itu modul yang dibuat oleh peneliti ini menggunakan desain cover yang sesuai dengan karakteristik siswa Sekolah Dasar sehingga dapat menarik minat membaca siswa. Selain itu biasanya modul hanya dilengkapi latihan soal yang monoton. Namun pada modul yang akan dibuat oleh peneliti kali ini soal-soal evaluasi dikemas secara menarik dalam bentuk soal rutin dan non rutin yang dapat meningkatkan kemampuan belajar siswa. Selain itu materi yang disampaikan sangat luas dan disertai dengan contoh soal beserta penyelesaiannya. Gaya Bahasa yang digunakan dalam modul ini pun juga komunikatif sehingga siswa mudah untuk memahaminya.

komik merupakan media atau penyalur komunikasi visual yang memiliki daya tarik dalam menyampaikan informasi secara ringkas dan mudah dimengerti. Hal ini dikarenakan komik memadukan antara gambar dan tulisan 
yang disusun dalam sebuah alur cerita bergambar yang membuat informasi menjadi mudah diserap.

Peneliti memilih mata pelajaran matematika karena siswa cenderung tertarik dengan gambar dan alur cerita yang memuat angka. Matematika itu sendiri berasal dari Bahasa latin manthanein atau mathema yang berarti belajar atau hal yang dipelajari. Matematika

\section{METODE PENELITIAN}

Penelitian yang laksanakan ini termasuk dalam jenis penelitian pengembangan atau Research and Development (R\&D) dengan model pengembangan ADDIE yang terdiri dari lima termasuk dalam salah satu mata pelajaran yang diberikan di SD karena matematika memberikan siswa untuk dapat berpikir logis, analitis, sistematis, kritis, dan kreatif, serta kemampuan bekerja sama. Untuk itu peneliti memilih matematika untuk dasar materi pada media komik.

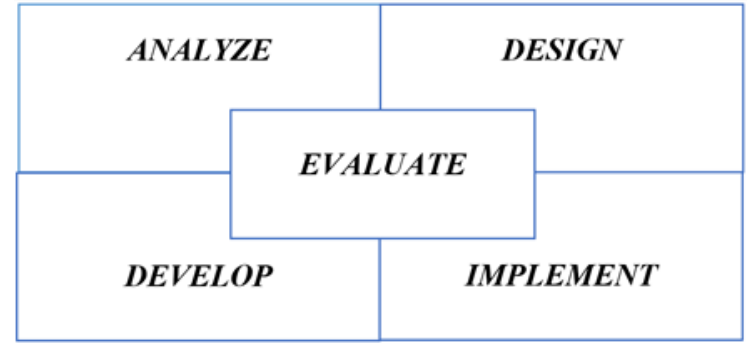

Gambar 1. Model ADDIE

Berikut ini penjelasan dari kelima tahapan ADDIE dalam pembuatan bahan ajar Komik berbasis modul ini.

Analisis (Analyze)

Pada tahap ini seorang peneliti akan melakukan dua tahapan analisis, yaitu melakukan analisis kurikulum dan materi serta menganalisis kebutuhan (need Analyze). Subyek dalam penelitian ini adalah guru dan siswa kelas V SD Negeri Pledokan 01, Kecamatan Sumowono, Kabupaten Semarang.

\section{Tahap Perancangan (Design)}

Pada tahap ini, peneliti melakukan perancangan (design) menyusun modul pembelajaran berbasis komik pada Materi Bangun Ruang kelas V SD.

Tahapan yang dilakukan oleh peneliti dalam menyusun sebuah modul yaitu: Menentukan judul dan tema modul pembelajaran, Mengumpulkan referensi, Menyusun kerangka modul pembelajaran, Merancang pembelajaran tahap yaitu Analyze, Design, Development, Implementation, dan Evaluation. Berikut ini merupakan model desain pembelajaran ADDIE yang dapat dilihat pada gambar 1 . 
menggunakan modul Materi Bangun Ruang berbasis komik. Hasil dari pretest, posttest, dan angket ini digunakan sebagai dasar untuk mengetahui efektivitas penggunaan modul Materi Bangun Ruang berbasis komik yang telah dibuat.

Tahap Evaluasi (Evaluation)

Tahap evaluasi ini dilakukan untuk menganalisis kelayakan dan efektivitas modul Materi Banguj Ruangberbasis komik berdasarkan uji coba di lapangan. Produk dikatakan valid melalui proses penilaian validator dengan lembar validasi ahli berdasarkan lembar penilaian media modul dan lembar penilaian materi. Sedangkan efektivitas produk diukur dari peningkatan hasil pretest dan posttest sekaligus hasil respon dari siswa.

\section{Teknik Analisis Data}

Data hasil perhitungan validasi produk kemudian dianalisis menggunakan teknik deskriptif persentase dan kategoris, tujuannya untuk mengetahui kelayakan media yang telah dikembangkan. Skor hasil pengukuran dengan menggunakan angket tertutup lalu dipersentasekan dengan menggunakan rumus:

$\mathrm{AP}=\frac{\text { Skor Aktual }}{\text { Skor Ideal }} \times 100 \%$

Keterangan

$\mathrm{AP} \quad=$ Angka Persentase

Skor Aktual $=$ Skor yang diberikan validator

Skor Ideal $=$ Skor maksimal hasil kali antara jumlah dengan skor maksimal masing masing item

Rentang angka persentase selanjutnya dikelompokkan menjadi lima kategori yang dapat dilihat sebagai berikut:

Tabel 1. Kategori Validasi Produk

\begin{tabular}{cl}
\hline Interval & \multicolumn{1}{c}{ Kategori } \\
\hline $81-100 \%$ & Sangat tinggi \\
\hline $61-80 \%$ & Tinggi \\
\hline $31-60 \%$ & Cukup \\
\hline $21-40 \%$ & Rendah \\
\hline $1-20 \%$ & Sangat rendah \\
\hline
\end{tabular}

Berdasarkan rentang angka persentase dan kategori di atas, maka media komik dinyatakan layak dan dapat diujicobakan di sekolah apabila mendapat angka persentasi minimal $\geq 61 \%$ dengan kategori tinggi. Kepraktisan dilakukan dengan analisis hasil respon siswa ketika uji coba terbatas media komik. Keefektifan dilakukan dengan analisis one grup design pretest-posttest menggunakan kriteria kemampuan pemecahan

\section{HASIL DAN PEMBAHASAN}

Penelitian ini dilakukan sesuai dengan desain pengembangan ADDIE, tahapan meliputi 1) Analysis, 2) Design, 3) Development, 4) Implementation, dan 5) Evaluation. Langkahlangkah pembuatan model pembelajaran Guidif adalah sebagai berikut. masalah yang encakup 5 aspek, meliputi aspek memahami masalah, merencanakan penyelesaian, melaksanakan penyelesaian, dan memeriksa kembali. Hasil dari ketiga kriteria digunakan untuk menentukan skor akhir. Skor akhir sebelum dan sesudah penerapan media dibandingkan dengan uji T sampel berpasangan (Paired Samples T Test) melalui SPSS 16.0 for windows. 
menyajikan materi belum menggunakan motode yang bervariatif, masih banyak menggunakan ceramah sehingga pembelajaran kurang menarik dan siswa mudah bosan, tidak berani mengemukakan pendapat dan mengakibatkan hasil belajat siswa pada mata pelajaran Matematika menjadi rendah.

Analisis kebutuhan dilakukan untuk mengetahui kompetensi yang perlu dipelajari siswa dalam pembelajaran. Berdasarkan hasil angket yang diberikan peneliti, diketahui bahwa siswa Kelas V yang berjumlah 20 orang sudah mengenal materi dassar bangun ruang . Langkah selanjutnya yang dilakukan peneliti adalah wawancara dengan beberapa siswa. Berdasarkan hasil wawancara, siswa belum pernah mengerjakan soal dengan menuliskan langkah-langkah penyelesaian. Dari penjelasan guru didapat informasi bahwa siswa masih kebingungan jika diajrkan tmenggunakan inovasi pembelajaran.

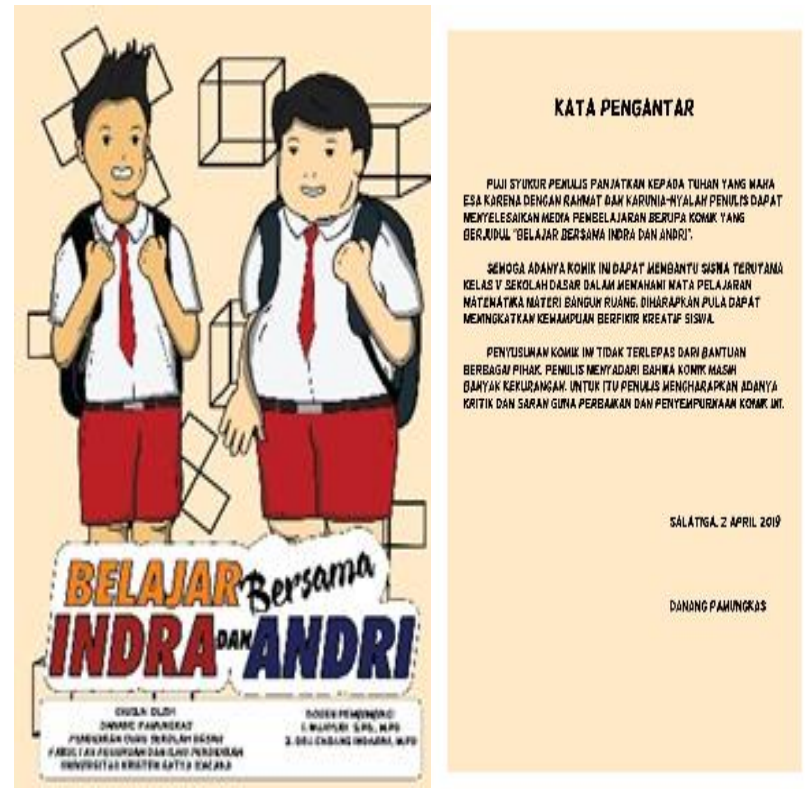

\section{Perancangan (Design)}

Langkah pertama yang dilakukan peneliti dalam perancangan yakni menetapkan judul komik yaitu Belajar Bersama Indra dan Andri. Kemudian menyiapkan sumber dari buku maupun referensi lain yang mendukung seperti internet, melakukan identifikasi terhadap Kompetensi Dasar pada aspek kognitif dan aspek keterampilan, melakukan identifikasi pada indikator pencapaian kompetensi serta membuat bentuk penilaian yang akan disajikan. Setelah itu merancang media pembelajaran berupa komik dan menyusun rencana pelaksanaan pembelajaran (RPP). Perancangan dilakukan dengan menyusun komik menggunakan beberapa aplikasi yakni Corel Draw X7 untuk menghasilkan bentuk desain. Komponen media komik antara lain: kata pengantar, deskripsi media komik, aturan membaca komik, pemetaan Materi, Kelas / Semester, Kompetensi Dasar, Indikator, penugasan, dan motivasi belajar.

Berikut ini adalah contoh tampilan komik yang telah dibuat:
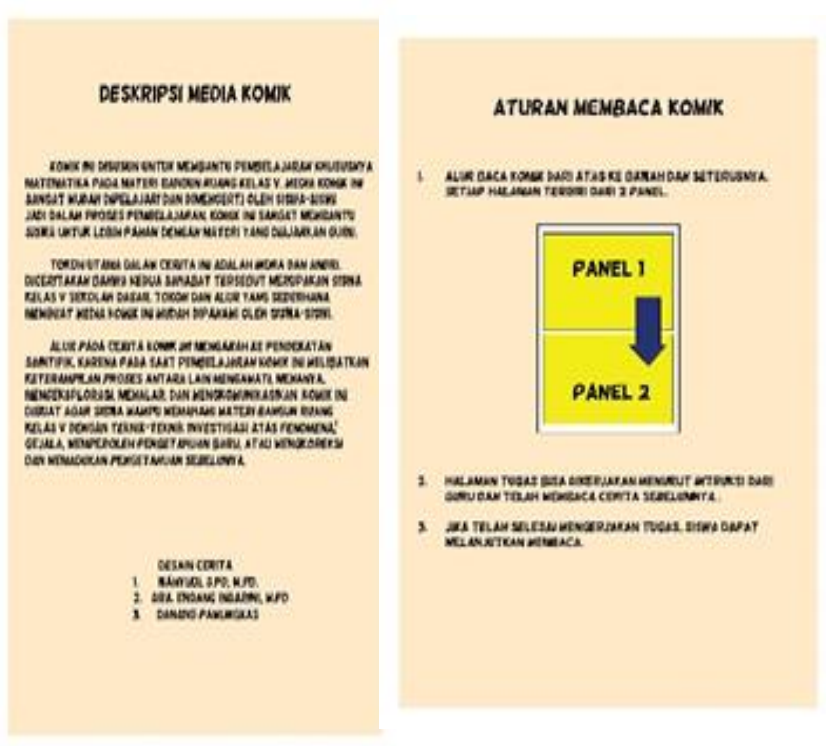

Gambar 2. Cover Komik, Kata Pengantar, Deskripsi Media Komik, dan Aturan Membaca Komik 

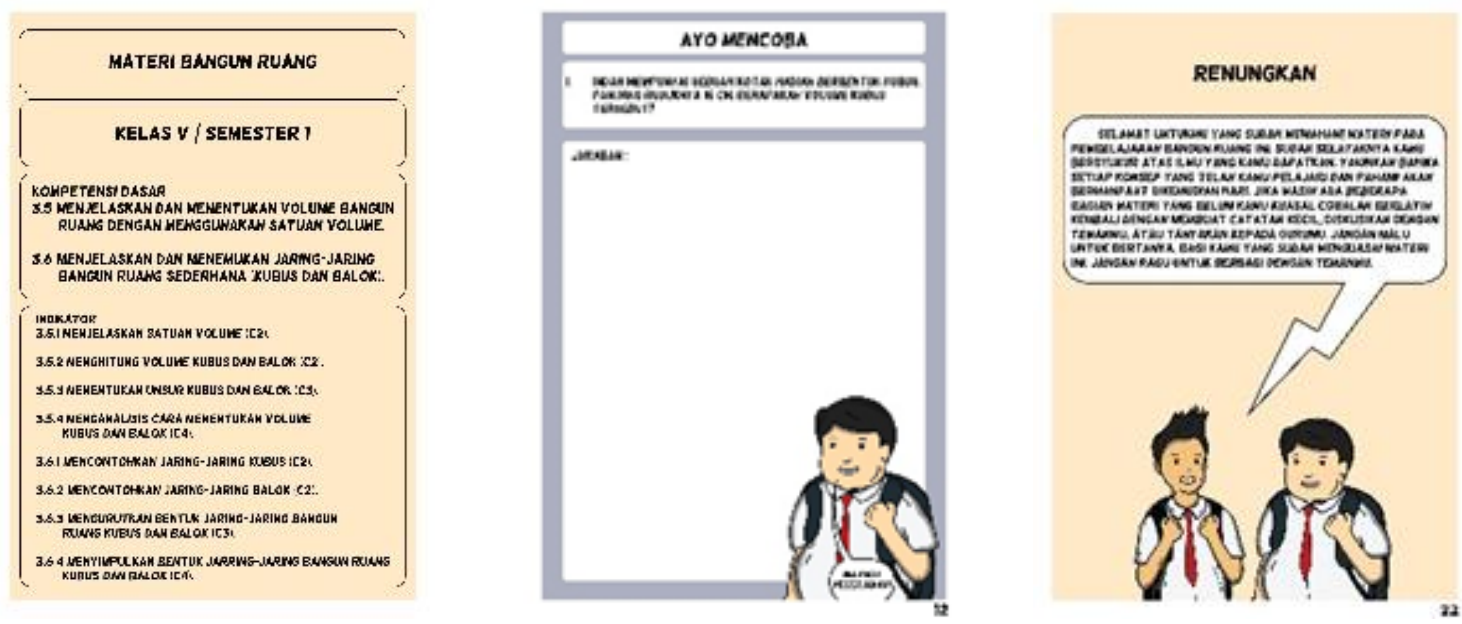

Gambar 3. Pemetaan KD dan Indikator, Penugasan, dan Motivasi Belajar

Pengembangan (Development)

Pengembangan media komik Belajar Bersama Indra akan melalui tahap validasi produk oleh pakar materi, pakar media, pakar pembelajaran, dan pakar soal. Validasi dilakukan agar mengetahui kelayakan produk sebelum diujicobakan ke sekolah. Berikut ini adalah pengembangan dari komik.

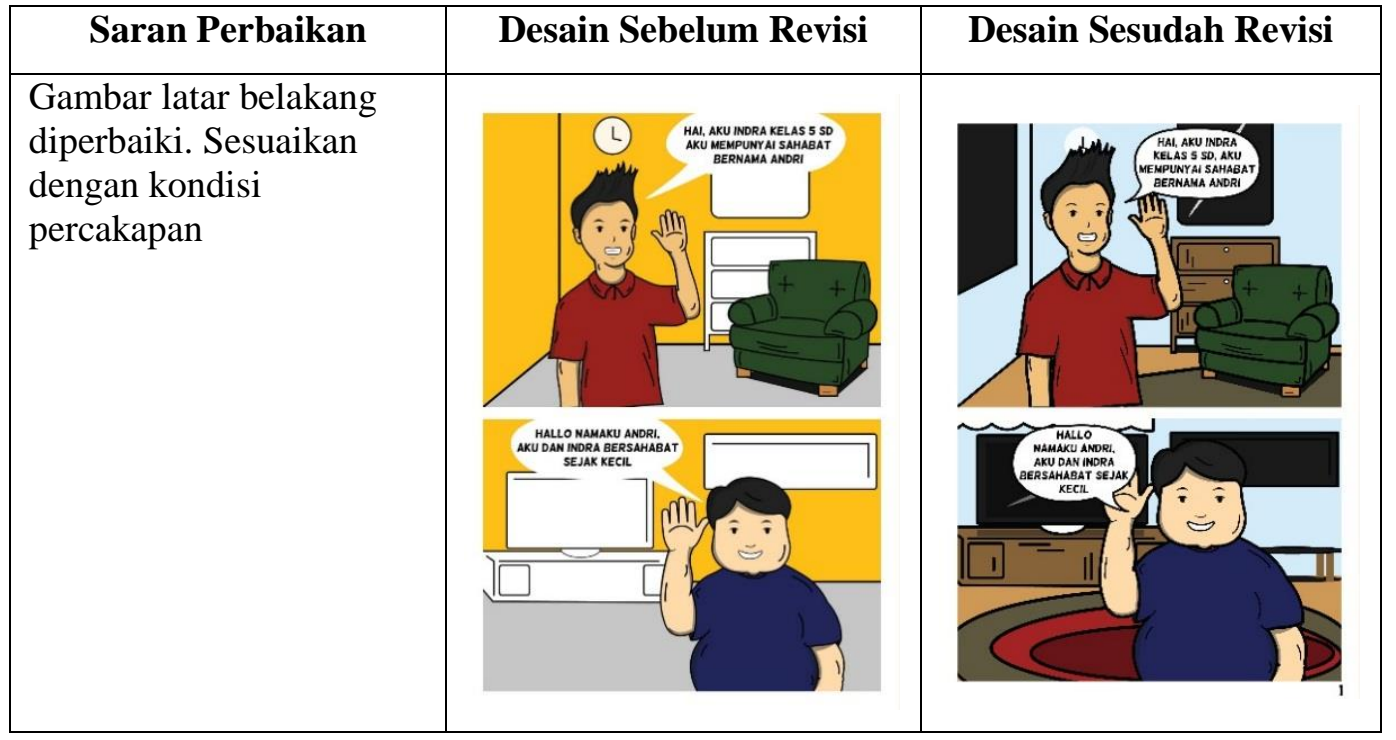

Tabel 1. Hasil Penilaian Pakar

\begin{tabular}{llcccc}
\hline No & Indikator & Skor Ideal & Skor Aktual & AP(\%) & Kategori \\
\hline 1. & Materi pembelajaran & 55 & 39 & $71 \%$ & Tinggi \\
\hline 2. & Media pembelajaran & 65 & 46 & $71 \%$ & Tinggi \\
\hline 3. & Pembelajaran & 65 & 50 & $77 \%$ & Tinggi \\
\hline
\end{tabular}


Berdasarkan kriteria kelayakan media yang telah dikembangkan oleh peneliti, untuk itu pada indikator materi pembelajaran, media pembelajaran, dan pembelajaran dapat dikatakan dalam kategori tinggi (nilai persentase $\geq 61$ ), sehingga media layak digunakan.

\section{Implementasi (Implementation)}

Peneliti melakukan langkah analisis yakni angket respon siswa dari hasil uji coba terbatas, hasil analisis data dari penilaian kemampuan pemecahan masalah pada masing-masing aspek soal pretest dan posttest, serta hasil penilaian presentasi. Hasil analisis angket respon siswa terlihat pada tabel 2 berikut.

Tabel 2. Hasil Angket Respon Siswa

\begin{tabular}{|c|c|c|c|}
\hline \multirow{2}{*}{ No } & \multirow{2}{*}{ Indikator Penilaian } & \multicolumn{2}{|c|}{ Skor } \\
\hline & & Ya & Tidak \\
\hline 1. & $\begin{array}{l}\text { Saya tertarik belajar dengan menggunakan media komik Belajar Bersama } \\
\text { Indra dan Andri }\end{array}$ & 20 & - \\
\hline 2. & $\begin{array}{l}\text { Saya senang dapat belajar dengan menggunakan media komik Belajar } \\
\text { Bersama Indra dan Andri }\end{array}$ & 20 & - \\
\hline 3. & Saya dapat menjelaskan materi yang ada dalam media & 16 & 4 \\
\hline 4. & Saya mendapat petunjuk penggunaan media & 19 & 1 \\
\hline 5. & $\begin{array}{l}\text { Permasalahan yang ada pada media sering saya temukan pada kehidupan } \\
\text { sehari-hari }\end{array}$ & 15 & 5 \\
\hline 6. & Saya dapat membaca tulisan yang ada pada media & 20 & - \\
\hline 7. & Dengan menggunakan media dapat menambah pengetahuan saya & 20 & - \\
\hline 8. & Saya dapat memahami Bahasa yang ada pada media & 17 & 3 \\
\hline & Jumlah & 147 & 13 \\
\hline & Presentase & $92 \%$ & $8 \%$ \\
\hline
\end{tabular}

Berdasarkan hasil angket respon siswa setelah pembelajaran di kelas menggunakan media komik didapatkan hasil 92\% siswa mampu memahami isi dari komik, sehingga dapat disimpulkan bahwa siswa terbantu dalam memahami materi dan memperoleh kepraktisan ketika menggunakan media komik.

Hasil data pemecahan masalah pada pretest dan posttest dapat dilihat dari tabel 3 berikut.

Tabel 3. Hasil Pretest dan Posttest

\begin{tabular}{lcccc}
\hline \multirow{2}{*}{\multicolumn{1}{c}{ Aspek }} & \multicolumn{2}{c}{ Pretest } & \multicolumn{2}{c}{ Posttest } \\
\cline { 2 - 5 } & Skor & Persentase & Skor & Persentase \\
\hline Memahami masalah & 52 & $65 \%$ & 68 & $85 \%$ \\
\hline Merencanakan penyelesaian & 39 & $49 \%$ & 74 & $92 \%$ \\
\hline Melaksanakan penyelesaian & 61 & $76 \%$ & 56 & $70 \%$ \\
\hline Memeriksa kembali & 36 & $45 \%$ & 42 & $52 \%$ \\
\hline
\end{tabular}

Dari hasil data pemecahan masalah pada pretest menunjukkan bahwa ada dua aspek kemampuan pemecahan masalah yang memperoleh persentase kurang dari 50\%, yaitu aspek merencanakan penyelesaian dengan persentase sebesar $49 \%$ dan aspek memeriksa kembali dengan persentase sebesar $45 \%$. Berbeda dengan hasil data pemecahan masalah pada posttest yang menunjukkan semua aspek dalam kemampuan pemecahan masalah memperoleh persentase lebih dari $50 \%$. Hasil posttest menunjukkan bahwa aspek memahami masalah memperoleh persentase sebesar 85\%, aspek merencanakan penyelesaian dengan persentase sebesar 92\%, aspek melaksanakan penyelesaian dengan persentase sebesar $70 \%$, dan aspek memeriksa kembali dengan persentase sebesar $52 \%$. 


\section{Evaluasi (Evaluation)}

Setelah tahap implementasi selanjutnya yaitu tahap evaluasi, peneliti megolah data pretest dan posttest menggunakan SPSS 16.0 for windows kemudian dilakukan uji Paired Samples
$T$ Test. Langkah yang harus dilakukan yakni Analyze- Compare means- Paired Samples T Test. Hasil dari uji tersebut disajikan pada table 4 sebagai berikut.

Tabel 4. Uji Paired Samples T Test

\begin{tabular}{|c|c|c|c|c|c|c|c|c|c|}
\hline & & \multicolumn{5}{|c|}{ Paired Differences } & \multirow[t]{3}{*}{$\mathrm{t}$} & \multirow[t]{3}{*}{$\mathrm{df}$} & \multirow{3}{*}{$\begin{array}{l}\text { Sig. (2- } \\
\text { tailed) }\end{array}$} \\
\hline & & \multirow[t]{2}{*}{ Mean } & \multirow[t]{2}{*}{$\begin{array}{c}\text { Std. } \\
\text { Deviati } \\
\text { on }\end{array}$} & \multirow[t]{2}{*}{$\begin{array}{l}\text { Std. } \\
\text { Error } \\
\text { Mean }\end{array}$} & \multicolumn{2}{|c|}{$\begin{array}{c}95 \% \\
\text { Confidence } \\
\text { Interval of the } \\
\text { Difference }\end{array}$} & & & \\
\hline & & & & & $\begin{array}{c}\text { Lowe } \\
\mathrm{r}\end{array}$ & $\begin{array}{c}\text { Uppe } \\
\text { r }\end{array}$ & & & \\
\hline Pair 1 & $\begin{array}{c}\text { PRETEST } \\
- \\
\text { POSTTES } \\
\mathrm{T} \\
\end{array}$ & -10.350 & 4.815 & 1.077 & $\begin{array}{c}- \\
12.60 \\
4\end{array}$ & $\begin{array}{c}- \\
8.096\end{array}$ & 9.612 & 19 & .000 \\
\hline
\end{tabular}

Berdasarkan hasil Uji Paired Samples T Test menunjukkan nilai Sig. (2-tailed) sama dengan 0.000 atau kurang dari 0.05 , sehingga

\section{Pembahasan}

Berdasarkan hasil dari penelitian, media komik dengan pendekatan Saintifik dapat meningkatkan kemampuan pemecahan masalah. Hal ini dikarenakan siswa memperoleh kemudahan belajar dalam mengerjakan soal yang diselesaikan menggunakan 4 langkah pemecahan masalah. Sejalan dengan Polya (dalam Wahyudi \& Anugraheni, 2017) menjelaskan bahwa terdapat empat langkah penyelesaian masalah, diantaranya: (1) pemahaman masalah (understanding the problem), (2) perencanaan penyelesaian (devising a plan), (3) melaksanakan perencanaan (carrying out the plan), dan (4) pemeriksaan kembali proses dan hasil (looking back).

Kemampuan pemecahan masalah bisa dimiliki siswa apabila siswa mendapatkan kesempatan yang sama. Oleh karena itu, media komik dirancang melalui pembelajaran dengan menggunakan metode Saintifik yang memberikan kesempatan siswa dalam aktif membaca dan mngerjakan soal dan individu atau kelompok.

Keberhasilan media komik untuk dapat dikatakan bahwa terdapat perbedaan yang signifikan antara hasil belajar pada pretest dan posttest.

meningkatkan kemampuan pemecahan masalah juga dipengaruhi oleh materi pembelajaran yang disajikan. Pembelajaran ini menggunakan masalah yang sering ditemui dalam kehidupan sehari-hari. Dengan masalah yang ada sehari-hari bisa dijadikan refrensi cerita pada komik, maka dapat mendorong kemampuan siswa dalam menggunakan kecerdasannya yakni memecahkan masalah yang sedang dihadapi. Hal ini sejalan dengan Gadner (dalam Al Maidah, Setyosari \& Kuswandi, 2017) dimana kecerdasan merupakan kemampuan dalam menyelesaikan masalah maupun menciptakan suatu produk yang berharga dalam lingkungan budaya dan masyarakat. Lebih lanjut, Gadner mengidentifikasi ada delapan kecerdasan meliputi (1) kecerdasan verballinguistik mengarah pada kemampuan dalam mengolah kata, (2) kecerdasan logis-matematis yakni kemampuan dalam memecahkan masalah, (3) kecerdasan visual-pasial yakni kemampuan dalam melihat serta mengamati secara cermat, (4) kecerdasan kinestetik yakni kemampuan gerakan tubuh untuk menyampaikan ide dan gagasan, (5) 
kecerdasan musikal yakni kemampuan yang berhubungan dengan musik seperti kepekaan musik yang didengar, (6) kecerdasan intrapersonal yakni kemampuan dalam memahami perasaan seseorang, (7) kecerdasan interpersonal yakni kemampuan akan kesadaran dan pengetahuan tentang diri sendiri, dan (8) kecerdasan naturalis yakni kemampuan dalam memahami, membedakan, menjelaskan serta

\section{SIMPULAN DAN REKOMENDASI}

Penelitian dan pengembangan (R\&D) yang telah dilaksanakan diperoleh hasil bahwa media komik dengan pendekatan saintifik untuk meningkatkan kemampuan pemecahan masalah di sekolah dasar efektif digunakan dalam pembelajaran. Hal ini ditunjukkan dari hasil belajar siswa berdasarkan Paired Samples T Test dengan Sig (2.tailed) sama dengan 0,000 atau kurang dari 0,05 , sehingga dapat dikatakan bahwa terdapat perbedaan yang signifikan antara hasil data pretest dan posttest. Hasil pretest menunjukkan bahwa siswa yang tuntas dengan nilai $\geq 70$ sebesar $35 \%$ atau sebanyak 7 siswa, sedangkan siswa yang tidak tuntas dengan nilai. sebesar 65\% atau sebanyak 13 siswa. Berbeda dengan hasil posttest yang menunjukkan bahwa siswa yang tuntas dengan nilai $\geq 70$ sebesar $90 \%$ atau sebanyak 18 siswa, sedangkan siswa yang tidak tuntas dengan nilai $<70$ sebesar $10 \%$ sebanyak 2 siswa. Kepraktisan media komik ditunjukkan dari hasil angket respon siswa setelah

\section{DAFTAR PUSTAKA}

Al Maidah, S. P. (2017). Pengembangan Bahan Ajar Tematik Cetak Semi Digital Berbasis Multiple Intelegences Untuk Siswa Kelas I Sd. Seminar Nasional Teknologi Pembelajaran dan Pendidikan Dasar, 1116.

Ariastutuik, E. K. (2016). Pengembangan Modul Matematika Berilustrasi Komik Pada Materi Skala dan Perbandingan Kelas VII SMP/MTS.

Kemendikbud. (2003). Undang-Undang Republik Indonesia Nomor 20 Tahun 2003 Tentang membuat kategori yang ditemui di alam sekitar. Dari delapan kecerdasan yang dimiliki individu akan saling bekerjasama, meskipun setiap individu memiliki taraf kemampuan yang berbeda. Kecerdasan yang paling menonjol akan mengimbangi kecerdasan lainnya saat memecahkan masalah, sehingga masing-massing individu memiliki tingkat pemecahan masalah yang berbeda.

menggunakan media komik dalam pembelajaran dengan persentase $93 \%$.

Peneliti memberikan saran kepada beberapa pihak yang ikut serta dalam dunia pendidikan. Bagi siswa yang sering melakukan aktivitas membaca buku cerita bertema pendidikan diharapkan dapat menambah pengetahuan melalui kegiatan pembelajaran. Bagi guru, agar dapat memilih dan memanfaatkan media pembelajaran yang sesuai dengan karakteristik siswa serta dapat menumbuhkan minat siswa untuk belajar. Bagi kepala sekolah, agar dapat mempertimbangkan pemanfaatan media pembelajaran yang sesuai dengan karakteristik siswa serta tuntutan pendidikan zaman sekarang. Bagi peneliti selanjutnya, diharapkan bias mengembangkan produk dari penelitian ini yang sesuai dengan perkembangan zaman, serta mempertimbangkan kelayakan, keefektifan, dan kepraktisan media untuk penelitian selanjutnya.

Sistem Pendidikan Nasional. Jakarta: Kemendikbud.

Kemendikbud. (2016). Permendikbud Nomor 22 Tahun 2016 Tentang Standar Proses Pendidikan Dasar dan Menengah . Jakarta: Kemendikbud.

Rusman. (2017). Belajar dan Pembelajaran Berorientasi Standar Proses Pendidikan . Jakarta: Kencana.

Wahyudi \& Anugraheni I. (2017). Strategi Pemecahan Masalah Matematika. Salatiga: Satya Wacana University Press. 